\title{
Impact of Crystalloid to PRBC Ratio in Patients with Exsanguinating Penetrating Abdominal Injuries: The Conundrum of Resuscitation
}

\author{
Chrissy Guidry, Marie Unruh, Marquinn Duke, Peter Meade, Norman E McSwain Jr, Juan C Duchesne
}

\begin{abstract}
Background: When intraoperative hemostatic resuscitation (IHR) implements high transfusion ratios of FFP:PRBC (>1:2), there is an associated increased survival in patients with exsanguinating penetrating abdominal injuries (EPAI). The impact of crystalloids: PRBC during IHR has not been analyzed. We hypothesize that minimizing the amount of intraoperative crystalloids:PRBC in combination with high ratio FFP: PRBC will correlate with a survival benefit in patients with EPAI.
\end{abstract}

Methods: This was a 9-year retrospective analysis of patients with EPAI at a Level 1 Trauma Center. EPAI was defined as any patient who received $>20$ units of PRBC during IHR. Intraoperative ratio for FFP:PRBC was recorded, and patients were placed in three separate categories accordingly: high $(>1: 2)$, mid $(1: 4-1: 2)$, and low ratio $(<1: 4)$ groups. Quantity of crystalloids used during each category was recorded and a ratio of crystalloids:PRBC calculated. Logistic regression model was applied to analyze impact of crystalloid:PRBC on mortality, comparing the high FFP:PRBC ratio group to the low FFP: PRBC ratio group.

Results: Intraoperative high ratio FFP:PRBC conveyed a $32 \%$ overall survival benefit when compared with low ratio groups. Patients that received a high ratio FFP:PRBC when compared to low ratio group, received less intraoperative crystalloids (calculated crystalloids:PRBC ratios 1:3.4 vs 1:1.1; $p=0.001$ ). Our logistic regression demonstrated a survival benefit with a high FFP:PRBC [OR 95\% 0.19, Cl (0.05-0.33), $p=0.003$ ] and the calculated low crystalloid:PRBC [OR 95\%; $0.11 \mathrm{Cl}(0.01$ $0.59), p=0.001]$.

Conclusion: We were able to demonstrate a survival advantage in patients with EPAI that received IHR of a high ratio of FFP:PRBC and a low ratio of crystalloids:PRBC. These findings suggest that in patients with EAPI requiring massive volumes of PRBC, the ratio of intraoperative FFP:PRBC should be high and crystalloids:PRBC should be low.

Keywords: Resuscitation, Crystalloid, Hemorrhage, Trauma.

How to cite this article: Guidry C, Unruh M, Duke M, Meade P, McSwain NE Jr, Duchesne JC. Impact of Crystalloid to PRBC Ratio in Patients with Exsanguinating Penetrating Abdominal Injuries: The Conundrum of Resuscitation. Panam J Trauma Critical Care Emerg Surg 2013;2(1):52-57.

Source of support: Nil

Conflict of interest: None declared

\section{RESUMEN}

Antecedentes: Cuando hemostasis de reanimación intraoperatorias (IHR) implementa la alta proporción de FFP:PRBC (>1:2), hay aumento de la sobrevida en pacientes con lesiones penetrantes abdominales exsanguinating (EPAI). El impacto de cristaloides, PRBC durante IHR no han sido analizadas. Hipotetizamos que minimizar cantidad de volume de cristaloides: PRBC junto con una alta relación FFP:PRBC se correlacionan con un beneficio de supervivencia en pacientes con EPAI.

Métodos: Este es un 9-año análisis retrospectivo de EPAI pacientes en un Centro de Trauma Nivel I. EPAI: Ios pacientes que recibieron $>20$ unidades de PRBC durante IHR. Intraoperatoria relación de FFP:PRBC fue grabada y los pacientes fueron divididos en grupos en consecuencia: 1. Alto $(>1: 2)$, 2. Media (1:4 - 1:2), y 3. Relación Baja (<1:4). Cantidad de cristaloides:PRBC fue calculado. Modelo de regresión logística se aplicó para analizar impacto de cristaloides:PRBC sobre la mortalidad, comparar la alta FFP:PRBC relación a Baja FFP:PRBC relación entre grupos.

Resultados: Intra-operatoria alto ratio FFP:PRBC transmitió un $32 \%$ de supervivencia global beneficio cuando en comparación con baja relación entre grupos. Los pacientes que recibieron un alto vs baja proporción FFP:PRBC recibido menos cristaloides (calculado cristaloides:PRBC ratios $1: 3$ vs $1: 1 ; p=0,001$ ). La regresión logística ha demostrado un beneficio en la supervivencia con un alto FFP:PRBC $[O R=0.19$, IC $(0.05-$ $0.33), p=0,003$ ], y el calculo de bajo cristaloides: PRBC [OR $=0.11 \mathrm{IC}(0.01-0.59), \mathrm{p}=0.001)]$.

Palabras claves: Resucitacion, Crystaloides, Fluidos, Resultados, Transfusion de plasma, Transfusion de sangre.

\section{INTRODUCTION}

Damage control laparotomy (DCL) increases survival rates in patients with exsanguinating penetrating abdominal injuries (EPAI). ${ }^{1-4}$ In this group of patients, the combination of trauma induced coagulopathy (TIC), metabolic acidosis, and hypothermia compose the lethal death triad associated with severe tissue injury and tissue hypoperfusion. Civilian and military studies have demonstrated a survival benefit when a close ratio resuscitation of fresh frozen plasma (FFP) to packed red blood cells (PRBC) is used in EPAI.-9

Resuscitation strategies in patients with EPAI have evolved throughout the years. Military resuscitation during 1960s used aggressive crystalloid resuscitation with no predefined transfusion ratio of blood component therapy. Fluid administration focused on crystalloid use in an effort to balance inputs and outputs. ${ }^{10,11}$ This approach failed to address the coagulopathy associated with severely injured patients in hemorrhagic shock.

Currently, the goal during intraoperative hemostatic resuscitation (IHR) consists of component therapy resuscitation that targets replacement of depleted blood volume, restoration of tissue perfusion and effective 
correction of coagulopathy. This resuscitation strategy has been accepted by many civilian trauma centers with overall improvement in outcomes. ${ }^{5-9,12-14}$ The etiology leading to this improvement could be multifactorial. During close ratio resuscitation, the goal should consist of FFP matched to PRBC in a 1:1 fashion while minimizing crystalloid utilization. No Level 1 data exist to support the amount of crystalloids that should be incorporated during IHR in exsanguinating patients, and the impact of crystalloid:PRBC ratio on mortality during IHR has not been analyzed. We hypothesize that minimizing the intraoperative crystalloid:PRBC ratio in combination with a high ratio for FFP:PRBC will correlate with a survival benefit in patients with EAPI.

\section{METHODS}

This is a 9-year retrospective review of adult patients with EAPI at a Level 1 urban trauma center. EAPI was defined as a penetrating abdominal injury requiring at least 20 units of PRBC in the operating room. Clearly defining hemorrhage is a difficult task, and our study population differs from patients commonly used in definitions of massive transfusion (where 10 units of blood is given over 24 hours). This patient population was selected in particular to study the most severe cases hemorrhagic shock. Patients were identified through the institutional trauma registry under an IRB-approved protocol.

A massive transfusion protocol (MTP) was activated for all patients included in this study. The MTP was changed in 2007 at our institution to have a goal of a matched 1:1 ratio of FFP:PRBC. However, this goal was not perfectly obtained during IHR for all patients. Therefore, patients were then separated into three groups according to the intraoperative ratio transfused for FFP:PRBC: High (>1:2), $\operatorname{mid}(1: 4-1: 2)$, and low ratio $(<1: 4)$. Intraoperative ratios were analyzed on patients' initial visit to the OR only. Crystalloid infusion guidelines are not part of the MTP at our institution. Each liter of crystalloids given was defined as 1 unit ( 1 liter = 1 unit). Fractional units of crystalloids were used in the comparison. In each group, the correlating crystalloid:PRBC ratio was then calculated.

Demographic and clinical data were retrieved from the trauma registry which included patients' age (years), emergency department initial systolic blood pressure $(\mathrm{mmHg})$, initial hemoglobin ( $\mathrm{gm} / \mathrm{dl})$, initial base deficit $(\mathrm{mEq} / \mathrm{l})$, and injury severity score (ISS). A focus of this study was to evaluate, specifically, intraoperative resuscitation on outcomes. Therefore, intraoperative units of PRBC, units of FFP and units of crystalloids ( 1 unit $=1$ liter) were also recorded. Operating room (OR) mortality was obtained as well as overall 30-day mortality.

\section{Statistical Methods}

Univariate analysis of continuous data was done with the Student's t-test on variables of age, initial systolic blood pressure, initial hemoglobin, initial base deficit and ISS. The mean amount of PRBC, FFP and crystalloids was studied by using analysis of variance (ANOVA). Using a chi-squared model, mortality differences were analyzed for each group. Logistic regression model, eliminating for confounders, was used in order to identify variables associated with improved survival by comparing high ratio to low ratio groups.

\section{RESULTS}

During the 9-year study at a level 1 trauma center, a total of 64 patients with penetrating abdominal injuries required greater than 20 units PRBCs during intraoperative resuscitation in the patients' initial surgery. Of the 64 patients transfused, 27 had a high IHR ratio of FFP:PRB (>1:2), 21 had a mid IHR ratio of FFP:PRBC (1:4 - 1:2), and 17 had a low IHR ratio of FFP:PRBC $(<1: 4)$. The correlating crystalloid:PRBC mean ratio was calculated in each IHR ratio group: High 1:3.4, mid 1:1.3, low 1:1.1 (Table 1).

There was no statistical difference demonstrated when comparing patient demographics and clinical data between a high $v s$ mid $v s$ low ratio: age $25 \pm 13$ years $v s 23 \pm 14$ years vs $24 \pm 11(\mathrm{p}=0.54)$, mean initial systolic pressure $88 \pm 26$ $\mathrm{mm} \mathrm{Hg} v s 92 \pm 31 \mathrm{~mm} \mathrm{Hg} v s 90 \pm 28 \mathrm{~mm} \mathrm{Hg}(\mathrm{p}=0.21)$, mean initial hemoglobin $9.3 \pm 1.2$ vs $10.1 \pm 1.4$ vs $9.9 \pm 1.5$ $(\mathrm{p}=0.53)$, mean initial base deficit $-9.9 \pm 4.2 v s-9.6 \pm 5.7$ $v s-9.1 \pm 4.8(\mathrm{p}=0.45)$, and the mean ISS $27 \pm 11$ vs $25 \pm$ $8(\mathrm{p}=0.71)($ Table 2$)$.

The mean PRBC units used in intraoperative resuscitation in each group was not statistically significant in high $v s$ mid vs low (32 vs 31 vs 33, p = 0.79). However, units of FFP and crystalloids used was found to be statistically significant between high $v s$ mid $v s$ low: mean units of FFP $26 v s 12 v s 7$ ( $\mathrm{p}=0.001)$ and mean units (liters) crystalloids $9.2 \mathrm{vs} 17 \mathrm{vs}$ $29(\mathrm{p}=0.002)$. (Table 3 and Fig. 1). We suspect the profound difference between the high $v s$ mid $v s$ low groups is due to differences in the MTP before 2007 and after 2007, when the protocol was changed from 1:4 to 1:1 of FFP:PRBC. After the initiation of 1:1, we suspect that the protocol was not perfectly achieved initially but rather slowly adapted to reflect current compliance to the protocol.

When comparing outcome mortality, high $v s$ mid $v s$ low groups demonstrated 30-day mortality of $56 v s 76 v s$ 88\% $(\mathrm{p}=0.009)$ and intraoperative mortality 19 vs 19 vs $29 \%$ $(\mathrm{p}=0.13)$ (Table 4 and Fig. 2).

In a logistic regression model after adjusting for age, ISS and systolic pressure, multivariate analysis showed that patients with EPAI demonstrated a survival benefit with a 
Impact of Crystalloid to PRBC Ratio in Patients with Exsanguinating Penetrating Abdominal Injuries

high FFP:PRBC IHR ratio [OR 0.19, (95\% CI 0.05-0.39), $\mathrm{p}=0.19]$ when compared to the low ratio FFP:PRBC ratio IHR. Additionally, a survival benefit was demonstrated in a low calculated ratio of crystalloid:PRBC [OR 0.11, (95\% CI 0.01-0.59), $\mathrm{p}=0.001]$ when compared against the high calculated ratio of crystalloid:PRBC (Table 5).

Intraoperative ratios of component therapy were calculated for FFP:PRBC and separated into three different groups: high (>1:2), $\operatorname{mid}(1: 4-1: 2)$ and low ratio $(<1: 4)$. The correlating crystalloid:PRBC ratio was then calculated in each group. The means for each group are represented here.
Component therapy in all ratio groups show a consist amount of PRBC. The utilization of FFP decreased from high to low ratio while crystalloid use increased. Patients in the low ratio group received the least amount of FFP with concomitant greatest amount of crystalloids. This group had the highest intraoperative mortality, $29 \%$ and overall 30 -day mortality, 88\% (see Figs 1 and 2).

Trends showing increase in mortality from high ratio to low ratio. Patients in the low ratio group, who received the greatest volume of crystalloids, had the highest overall mortality.

\begin{tabular}{lccc} 
& $\begin{array}{c}\text { Table 1: Intraoperative ratio groups } \\
\text { High ratio } \\
(n=27)\end{array}$ & $\begin{array}{c}\text { Mid ratio } \\
(n=21)\end{array}$ & $\begin{array}{c}\text { Low ratio } \\
(n=17)\end{array}$ \\
\hline Mean FFP:PRBC ratio & $1: 1.2$ & $1: 2.5$ & $1: 4.7$ \\
Mean crystalloid:PRBC & $1: 3.4$ & $1: 1.3$ & $1: 1.1$ \\
\hline
\end{tabular}

FFP: Fresh frozen plasma; PRBC: Packed red blood cells

$\begin{array}{lcccc} & \text { Table 2: Univariate analysis comparing FFP:PRBC groups high mid and low } & \\ & \begin{array}{c}\text { High ratio } \\ (n=27)\end{array} & \begin{array}{c}\text { Mid ratio } \\ (n=21)\end{array} & \begin{array}{c}\text { Low ratio } \\ (n=17)\end{array} & p \text {-value } \\ & 25(13) & 23(12) & 24(11) & 0.54 \\ \text { Age (SD) } & 88(26) & 92(31) & 90(28) & 0.21 \\ \text { ED SBP (SD) } & 9.3(1.2) & 10.1(1.4) & 9.9(1.5) & 0.53 \\ \text { Initial hemoglobin (SD) } & -9.9(4.2) & -9.6(5.7) & -9.1(4.8) & 0.45 \\ \text { Initial base deficit (SD) } & 27(11) & 25(8) & 27(10) & 0.71 \\ \text { ISS (SD) } & & \end{array}$

SD: Standard deviation; SBP: Systolic blood pressure; ISS: Injury severity score

\begin{tabular}{lcccc}
\multicolumn{1}{c}{ Table 3: Components in intraoperative resuscitation } & \\
& $\begin{array}{c}\text { High ratio } \\
(n=27)\end{array}$ & $\begin{array}{c}\text { Mid ratio } \\
(n=21)\end{array}$ & $\begin{array}{c}\text { Low ratio } \\
(n=17)\end{array}$ & $p$-value \\
\hline Mean PRBC (units) & 32 & 31 & 33 & 0.79 \\
Mean FFP (units) & 26 & 12 & 7 & $0.001^{*}$ \\
Mean crystalloids (liters) & 9.2 & 17 & 29 & $0.003^{*}$ \\
\hline
\end{tabular}

PRBC: Packed red blood cells; FFP: Fresh frozen plasma; *Statistical significance

\begin{tabular}{lcccc}
\multicolumn{5}{c}{ Table 4: 30-day mortality and OR mortality } \\
& $\begin{array}{c}\text { High ratio } \\
(n=27)\end{array}$ & $\begin{array}{c}\text { Mid ratio } \\
(n=21)\end{array}$ & $\begin{array}{c}\text { Low ratio } \\
(n=17)\end{array}$ & $p$-value \\
\hline 30-day mortality (\%) & $15 / 27(56 \%)$ & $16 / 21(76 \%)$ & $15 / 17(88 \%)$ & $0.009^{*}$ \\
OR mortality (\%) & $5 / 27(19 \%)$ & $4 / 21(19 \%)$ & $5 / 17(29 \%)$ & 0.13 \\
\hline
\end{tabular}

OR: Operating room; TICU: Trauma intensive care unit; *Statistical significance

Table 5: Logistic regression model for mortality

\begin{tabular}{lcc} 
& Table 5: Logistic regression model for mortality & Odds ratio (95\% Cl) \\
\hline High FFP:PRBC ratio & $p$-value & $0.19(0.05-0.33)$ \\
Low crystalloid:PRBC ratio & $0.003^{*}$ & $0.11(0.01-0.59)$ \\
ISS & $0.001^{*}$ & $1.02(0.98-1.101)$ \\
SBP & 0.13 & $1.34(0.43-4.17)$ \\
\hline
\end{tabular}

PRBC: Packed red blood cells; ISS: Injury severity score; SBP: Systolic blood pressure; * Statistical significance

The logistic regression model for mortality compared high ratio FFP:PRBC to low ratio FFP:PRBC, while low ratio crystalloid:PRBC was compared to high ratio crystalloid:PRBC 


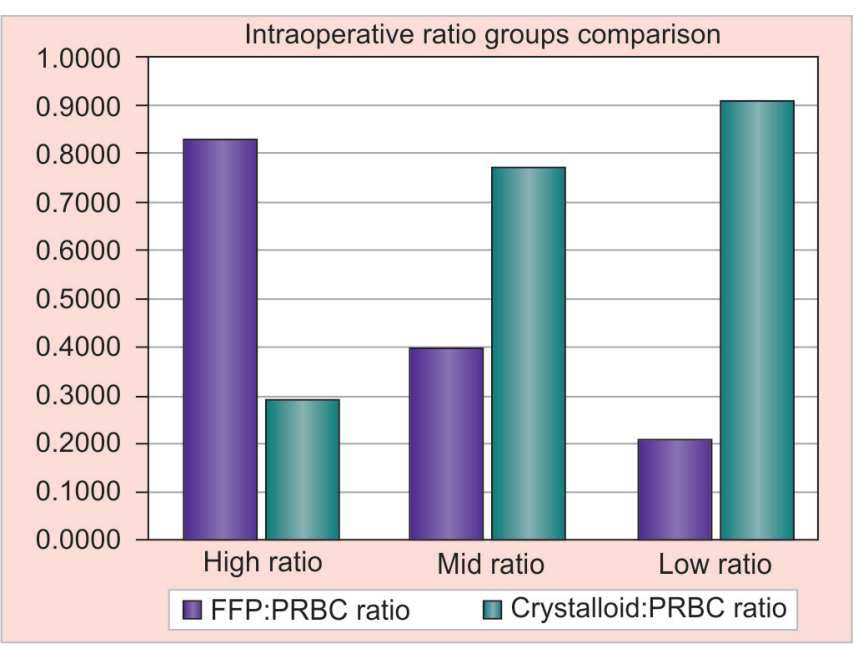

Fig. 1: Components in intraoperative resuscitation

\section{DISCUSSION}

Exsanguinating injuries are the cause of death in up to $40 \%$ of trauma victims. ${ }^{15}$ Survival has improved in the range of 6 to $50 \%$ by implementing hemostatic resuscitation as part of massive transfusion protocols. ${ }^{16}$ This volume replacement therapy aims to correct hemodynamic stability, TIC and tissue hypoperfusion. During the history of trauma resuscitation, crystalloids have been the standard of fluid resuscitation ${ }^{10,11,17,18}$ with ongoing recommendations of moderation and adaptations. ${ }^{12,19-21}$ Current advanced trauma life support (ATLS) guidelines call for initial infusion of 1 to 21 of crystalloid followed by transfusion of PRBC if transient or no response, when hemorrhagic shock is suspected. ${ }^{22,23}$ Using a newer strategy, damage control resuscitation (DCR) conveys a survival benefit ${ }^{5-8}$ while integrating early IHR with a goal of a fixed transfusion of 1:1 of FFP:PRBC, restriction of crystalloid infusion and permissive hypotension in conjunction with principles of damage control surgery. ${ }^{12}$

In this study, the principles of DCR were observed in the high ratio group. Components involved during IHR (FFP, PRBC and crystalloids) were analyzed. The quantity of PRBC given in each group was not statistically different among high, mid and low groups, $p=0.79$. While the quantity of FFP given was statistically less from the high to low groups, 26 to 7 ( $\mathrm{p}=0.001)$, the mean liters of crystalloids given intraoperatively was statistically greater from high to low groups 9.2 to $29(\mathrm{p}=0.003)$. This increase in intraoperative infusion of large volumes of crystalloid has many potential adverse consequences in the exsanguinating trauma patient. As it was demonstrated in our study, patients that received large volumes of crystalloids with low quantities of FFP carried the highest overall mortality, $88 \%$.

Previous studies have demonstrated the deleterious effects of aggressive crystalloid administration in patients

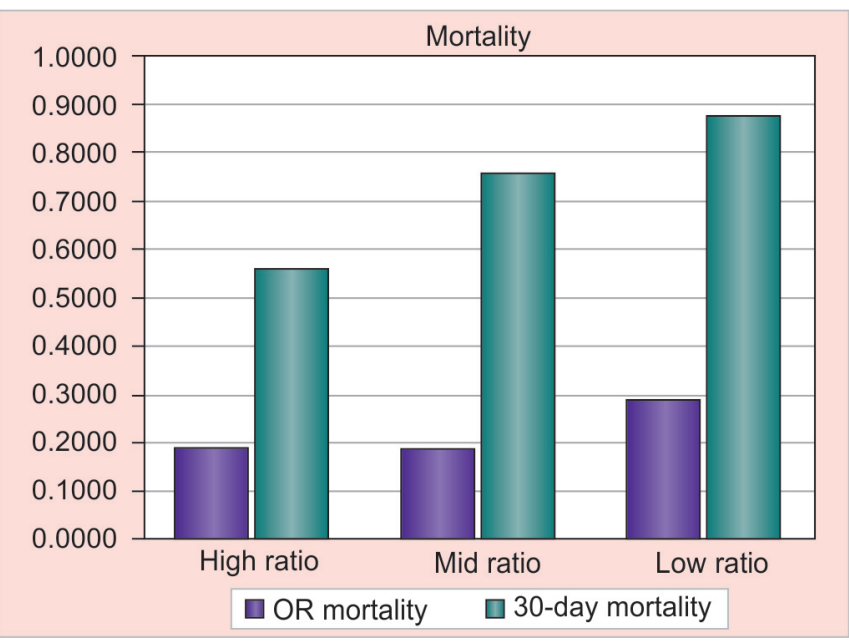

Fig. 2: Logistic regression model for mortality

with severe hemorrhage. ${ }^{24-26}$ Our results from this study support previous findings with evidence of decreased survival in patients with higher ratios of crystalloid:PRBC. Following major trauma, systemic inflammatory response is activated ${ }^{27,28}$ and capillary permeability increases causing a decrease in osmotic pressure intravascularly resulting in a loss of fluid to the interstitial space. Resuscitation with large crystalloid fluid volumes further potentiates cellular injury ${ }^{29}$ from imbalances occur in extracellular and intracellular osmolarity. With massive fluid shifts, cellular regulatory mechanisms become overwhelmed and resultant dysregulation of cellular mechanisms occurs: cytosolic acidification, dilution of cellular proteins and inactivation of protein kinases. ${ }^{25,30}$ The problematic fluid shifts manifest systemically causing pulmonary ${ }^{31-33}$ and cardiac complications ${ }^{25,34}$, abdominal compartment syndrome ${ }^{35-38}$, gastrointestinal dysmotility ${ }^{22}$, coagulation disturbances ${ }^{39-41,42}$, immunological and inflammatory mediator dysfunction. ${ }^{19,25,42-44}$

Taking into consideration the multitude of detrimental effects related to crystalloid administration, an essential goal of DCR is to minimize crystalloid usage. ${ }^{45}$ In our study, a logistic regression model demonstrated a survival advantage when FFP units was close to PRBC units, OR $0.19(0.05-0.33,95 \% \mathrm{CI}), \mathrm{p}=0.003$. Additionally, a low crystalloid:PRBC ratio also demonstrated a similar survival benefit, OR $0.11(0.01-0.59,95 \% \mathrm{CI}), \mathrm{p}=0.001$. This translates into improved outcomes with (1) less crystalloid per unit of PRBC and (2) a greater quantity of FFP per unit of PRBC. This suggesting not only a deleterious effect of crystalloids but perhaps a therapeutic effect of FFP.

The benefits of FFP are hypothesized by Pati et al to include a mechanism at the cellular level in combination of the replacement of coagulation factors. In their biological mechanism model, hemorrhagic shock induces hypoxia, 
endothelial cell tight junction breakdown, inflammation, and leukocyte diapedesis. The data in vivo and in vitro suggests that FFP has beneficial effects on vascular endothelial stability and resuscitation that are independent of its effects on hemostasis. They concluded that FFP repairs and 'normalizes' the vascular endothelium by restoring tight junctions, building the glycocalyx, and inhibiting inflammation and edema while crystalloid infusion will only potentiate vascular endothelial injury further. ${ }^{46}$

Perhaps future additions to MTPs will be standardized to include purposeful measures minimizing use of crystalloids. The advances in hemostatic resuscitation will likely further improve the survivability of trauma patients, especially in the extreme cases of hemorrhagic shock in exsanguinating abdominal penetrating injuries.

\section{CONCLUSION}

Future investigation of resuscitation will likely involve optimizing restoration of endothelial injury based on plasma and effective low volume fluid resuscitation. For patients with EPAI, there is a direct correlation with increased mortality and high infusion of crystalloid:PRBC. This suggests that minimizing the amount of intraoperative crystalloid:PRBC in patients requiring massive volumes of PRBC can improve survival.

\section{REFERENCES}

1. Duchesne JC, Kimonis K. Damage control resuscitation in combination with damage control laparotomy: A survival advantage. J Trauma 2010 Jul;69(1):46-52.

2. Rotondo MF, Zonies DH. The damage control sequence and underlying logic. Surg Clin North Am 1997;77:761-77.

3. Moore EE, Thomas G. Orr memorial Lecture. Staged laparotomy for the hypothermia, acidosis, and coagulopathy syndrome. Am J Surg 1996 Nov;172(5):405-10.

4. Lee JC, Peitzman AB. Damage-control laparotomy. Curr Opin Crit Care 2006;12:346-50.

5. Holcomb JB, Wade CE, Michalek JE, et al. Increased plasma to platelet to red blood cell ratios improves outcome in 466 massively transfused civilian trauma patients. Ann Surg 2008;248:447-58.

6. Gonzalez E, Moore F, Holcomb JB, et al. Fresh frozen plasma should be given earlier to patients requiring massive transfusion. J Trauma 2007;62:112-19.

7. Duchesne JC, Hunt JP, Wahl G, et al. Review of current blood transfusion strategies in a mature level in trauma center: Were we wrong for the last 60 years? J Trauma 2008;65:272-76.

8. Borgman MA, Spinella PC, Perkins JG, et al. The ratio of blood products transfused affects mortality in patients receiving massive transfusions at a combat support hospital. J Trauma 2007;63: 805-13.

9. Holcomb JB, Jenkins D, Rhee P, et al. Damage control resuscitation: Directly addressing the early coagulopathy of trauma. J Trauma 2007;62:307-10.
10. Shires GT, Coln D, Carrico J, et al. Fluid therapy in hemorrhagic shock. Arch Surg 1964; 88:688-93.

11. Dillon J, Lunch LJ, Myers R, et al. A bioassay of treatment of hemorrhagic shock. Arch Surg 1966;93:537-55.

12. Duchesne JC, Barbeau JM, Islam TM, Wahl G, Greiffenstein P, McSwain NE Jr. Damage control resuscitation: From emergency department to the operating room. Am Surg 2011 Feb;77(2): 201-06.

13. Cotton BA, et al. Damage control hematology: The impact of a trauma exsanguination protocol on survival and blood product utilization. J Trauma 2008;64:1177-83.

14. Duchesne JC, Islam TM, Stuke L, Timmer JR, Barbeau JM, Marr $\mathrm{AB}$, et al. Hemostatic resuscitation during surgery improves survival in patients with traumatic-induced coagulopathy. J Trauma 2009;67(1):33-7; discussion 37-39.

15. Sauaia A, Moore FA, Moore EE, Moser KS, Brennan R, Read RA, Pons PT. Epidemiology of trauma deaths: A reassessment. J Trauma 1995 Feb;38(2):185-93.

16. Cinat ME, Wallace WC, Nastanski F, et al. Improved survival following massive transfusion in patients who have undergone trauma. Arch Surg 1999;134:964-70.

17. Shires GT, Carrico CJ, Baxter CR, et al. Principles in treatment of severely injured patients. Adv Surg 1970;4:255-324.

18. Counts RB, Haisch C, Simon TL, Maxwell NG, Heimbach DM, Carrico CJ. Hemostasis in massively transfused trauma patients. Ann Surg 1979 Jul;190(1):91-99.

19. Rhee P, Koustova E, Alam HB. Searching for the optimal resuscitation method: Recommendations for the initial fluid resuscitation of combat casualties. J Trauma 2003;54:S52-62.

20. Moore FD, Shires G. Moderation. Ann Surg 166:300Y301, 1967.

21. Soreide E, Deakin CD. Pre-hospital fluid therapy in the critically injured patient-a clinical update. Injury 2005;36:1001-10.

22. American College of Surgeons Committee on Trauma. Advanced Trauma Life Support for Doctors: Student Course Manual (8th ed). Chicago, IL: American College of Surgeons Committee on Trauma 2008:63.

23. Asensio J, Trunkey D. Prehospital fluid resuscitation: what type, how much, and controversies. In: Current Therapy of Trauma and Surgical Critical Care. Philadelphia, PA: Mosby 2008.

24. Choi P, Yip G, Quinonez L, Cook D. Crystalloids vs colloids in fluid resuscitation: A systematic review. Crit Care Med 1999;27:200-10.

25. Cotton BA, Guy JS, Morris JA Jr, et al. The cellular, metabolic, and systemic consequences of aggressive fluid resuscitation strategies. Shock 2006;26:1 15-21.

26. Brakenridge SC, et al. Early blood product and crystalloid volume resuscitation: Risk association with multiple organ dysfunction after severe blunt traumatic injury. J Trauma 2011;71:299-305.

27. Lederer JA, Rodrick ML, Mannick JA. The effects of injury on the adaptive immune response. Shock 1999 Mar;11(3):153-59.

28. Harris BH, Gelfand JA. The immune response to trauma. Semin Pediatr Surg 1995 May;4(2):77-82.

29. Committee on fluid resuscitation for combat casualties. Fluid resuscitation: State of the science for treating combat casualties and civilian trauma. Report of the Institute of Medicine. Washington: National Academy Press 1999.

30. Lang F, Busch GL, Ritter M, Volkl H, Waldegger S, Gulbins E, Haussinger D. Functional significance of cell volume regulatory mechanisms. Physiol Rev 1998;78:248-73.

31. Bishop MA, Jorgens J, Shoemaker WC, Appel PL, Fleming A, Williams D, et al. The relationship between ARDS, pulmonary 
infiltration, fluid balance and hemodynamics in critically ill surgical patients. Am Surg 1991;57:785-92.

32. Rackow EC, Weil MH, Macneil AR, Makabali CG, Michaels S. Effects of crystalloid and colloid fluids on extra vascular lung water in hypoproteinemic dogs. J Appl Physiol 1987;62:2421-25.

33. Shoemaker WC, Hauser CJ. Critique of crystalloid versus colloid therapy in shock and shock lung. Crit Care Med 1979;7:117124,1979 .

34. Holte K, Sharrock NE, Kehlet H. Pathophysiology and clinical implications of perioperative fluid excess. Br J Anaesth 89:622632, 2002.

35. Raeburn CD, Moore EE, Biffl WL, Meldrum DR, Offner PJ, Franciose RJ, Burch JM. The abdominal compartment syndrome is a morbid complication of post injury damage control surgery. Am J Surg 2001;182:542-46.

36. Biffl WL, Moore EE, Burch JM, Offner PJ, Franciose RJ, Johnson JL. Secondary abdominal compartment syndrome is a highly lethal event. Am J Surg 2001;182:645-48.

37. Balogh Z, McKinley B, Cocanour CS, Kozar RA, Valdivia A, Sailors MR, Moore FA. Supra-normal trauma resuscitation causes more cases of abdominal compartment syndrome. Arch Surg 2003; 138:637-43.

38. Maxwell RA, Fabian TC, Croce MA, Davis KA. Secondary abdominal compartment syndrome: An underappreciated manifestation of severe hemorrhagic shock. J Trauma 1999;47:995-99.

39. Ledgerwood A, Lucas C. A review of studies on the effects of hemorrhagic shock and resuscitation on the coagulation profile. J Trauma 2003;54:S68-74.

40. Brohi K, Cohen M, Davenport R. Acute coagulopathy of trauma: mechanism, identification, and effect. Curr Opin Crit Care 2007; 13:680-85.

41. Hess J, Brohi K, Dutton R, et al. The coagulopathy of trauma: A review of mechanisms. J Trauma 2008;65:748-54.

42. Barak M, Rudin M, Vofsi O, Droyan A, Katz Y. Fluid administration during abdominal surgery influences on coagulation in the postoperative period. Curr Surg 2004;61:459-62.

43. Watters JM, Jackson T, Muller PJ, Malinoski D, Todd SR, Schreiber MA. Fluid resuscitation increases inflammatory response to traumatic injury. J Trauma 2004;57:1378. Oral presentation at the Eighteenth Annual Scientific Meeting of the Eastern Association for the Surgery of Trauma. January 10 Y 15, 2005; Ft Lauderdale, FL.

44. Eberhard LW, Morabito DJ, Matthay MA, Mackersie RC, Campbell AR, Marks JD, et al. Initial severity of metabolic acidosis predicts development of acute lung injury in severely traumatized patients. Crit Care Med 2000;28:125-31.

45. Rotondo MF, Schwab CW, McGonigal MD, et al. Damage control: An approach for improved survival in exsanguinating penetrating abdominal injury. J Trauma 1993;35:375-82, discussion 382-83

46. Pati S, Matijevic N, Doursout MF, Ko T, Cao Y, Deng X, et al. Protective effects of fresh frozen plasma on vascular endothelial permeability, coagulation, and resuscitation after hemorrhagic shock are time dependent and diminish between days 0 and 5 after thaw. J Trauma 2010 Jul;69 Suppl 1:S55-63.

\section{ABOUT THE AUTHORS}

\section{Chrissy Guidry}

Department of Surgery, Tulane University School of Medicine, Section of Trauma, New Orleans, LA

\section{Marie Unruh}

Department of Surgery, Tulane University School of Medicine, Section of Trauma, New Orleans, LA

\section{Marquinn Duke}

Department of Surgery, Tulane University School of Medicine, Section of Trauma, New Orleans, LA

\section{Peter Meade}

Department of Surgery, Tulane University School of Medicine, Section of Trauma, New Orleans, LA

\section{Norman E McSwain Jr}

Department of Surgery, Tulane University School of Medicine, Section of Trauma, New Orleans, LA

\section{Juan C Duchesne (Corresponding Author)}

Director of Surgical Intensive Care Unit, Department of Surgery and Anesthesia, Section of Trauma and Critical Care Surgery, Tulane University School of Medicine, 1430 Tulane Ave., SL-22, New Orleans, LA 70112-2699, Phone: 504-988-5111, Fax: 504-988-3683 e-mail: jduchesn@tulane.edu 